\title{
THE RESIDUAL EFFECT OF PRIOR DROP JUMPS ON CARDIO RESPIRATORY PARAMETERS DURING MODERATE CYCLING IN YOUNG WOMEN
}

Neringa Baranauskienė, Arvydas Stasiulis

Lithuanian Academy of Physical Education, Kaunas, Lithuania

\begin{abstract}
Research background and hypothesis. Unaccustomed prior drop jumps (PDJ) can cause muscle damage with concomitant delayed onset muscle soreness (DOMS) and decreased concentric contraction performance efficiency, but the residual effect of PJD on cardio respiratory system parameters during moderate cycling exercise (MC) remains equivocal. We suppose that DOMS, induced of PDJ, has altered cardio respiratory system parameters during MC exercises.

Research aim of the study was to assess the residual effect of 100 prior drop jumps on cardio respiratory system parameters kinetics during moderate cycling exercise.

Research methods. On four different days 10 women performed one increasing and three (control, $45 \mathrm{~min}$ and $24 \mathrm{~h}$ after 100 drop jumps) MC (Ergoline-800, Germany) exercises. The cadence of cycling was $70 \mathrm{rpm}$. The oxygen uptake $\left(\dot{V}_{2}\right)$, carbon dioxide output $\left(\dot{V}_{C O}\right)$; minute ventilation $\left(V_{E}\right)$ and heart rate $(H R)$ were continuously recorded during MC. Subjects rated their perceived exertions at the end of MC, and the DOMS was rated $24 \mathrm{~h}$ after PDJ.

Research results. After $24 \mathrm{~h}$ the subjects felt moderate DOMS (5.0 (2.79)) according to 10 point scale. The $\dot{V} o_{2}$; $\dot{V} \mathrm{CO}_{2}$ and $H R$ kinetics were unaltered by moderate DOMS after 45 minutes and 24 hours, but $V_{E}$ tended to increase 45 minutes after PDJ. The negative correlation between DOMS and $\dot{V}_{2}(\mathrm{r}=-0.52)$ was observed.

Discussion and conclusion. Prior drop jumps seem not to have significant residual effect on cardio respiratory parameters kinetics after 45 minutes or 24 hours, but they tend to increase $V_{E}$ after 45 minutes of recovery during moderate cycling exercise in young women.
\end{abstract}

Keywords: delayed onset muscle soreness, oxygen uptake, constant load.

\section{INTRODUCTION}

U naccustomed eccentric exercise, which involves active lengthening of muscle, induce delayed muscle soreness (DOMS) with concomitant damage and disarrangement of muscle fibers (Hortobagy et al., 1998; Stupka et al., 2000; Laanksonen et al., 2006; Malm, Yu, 2012), elevates creatine kinase activity (Gleeson et al., 1995; Stupka et al., 2000; Skurvydas et al., 2010; Chen et al., 2011) and reduces muscle force production and performance (Laanksonen et al., 2006; Semmler et al., 2007; Chen et al., 2010; Gorianovas et al., 2010; Skurvydas et al., 2010).
Residual effect of prior drop jumps (PDJ) as a form of eccentric - concentric exercise on cardio respiratory system parameters during constant cycling remains equivocal. No residual effect of PDJ has been observed on $\dot{V} O_{2}$, minute ventilation $\left(V_{E}\right)$ and heart rate $(H R)$ during the steady state phase of moderate cycling $(70 \mathrm{~W})$, but increased $\dot{V} O_{2}$ and $V_{E}$ during the steady state phase of heavy cycling one hour after PDJ have been reported in men (Ratkevičius et al., 2006). Moreover, the moderate DOMS induced of bench stepping exercise did not appear to impact $\dot{V} O_{2}$ during 
heavy cycling 48 and $72 \mathrm{~h}$ after eccentric exercise in women (Schneider et al., 2007) or eccentric squatting exercises in men (Gleeson et al., 1995; Moysi et al., 2005; Twist, Eston, 2009). Contrary, significant increases in $\dot{V} \mathrm{O}_{2}$ during steady state of moderate intensity running performed one hour after prior drop jumps with straight legs have been found in women (Zaičenkovienè, Stasiulis, 2010) as well as increased $V_{E}$ during moderate and severe cycling performed 48 hours after comprising squats in men (Davies et al., 2009). Nevertheless, we could not find data about the residual effect of prior eccentric-concentric exercises on cardio respiratory parameters within 24 hours of recovery during moderate intensity cycling exercise (MC) in women.

The aim of the study was to assess the residual effect of 100 prior drop jumps PDJ on oxygen uptake $\left(\dot{V}_{O_{2}}\right)$, carbon dioxide output $\left(\dot{V}_{C O} O_{2}\right)$; minute ventilation $\left(V_{E}\right)$ and heart rate $(H R)$ during moderate cycling exercise $\mathrm{MC}$ in young women.

\section{RESEARCH METHODS}

Participants. Ten healthy young women (anthropometry and physical characteristics are presented in Table 1) volunteered to participate in this study after giving written informed consent. The subjects were physically active but did not take part in any formal physical exercise or sport program. The experimental protocol was approved by the Lithuanian Ethical Committee of Kaunas University of Medicine and conducted in accordance with the Declaration of Helsinki.

Ergometer cycling and data collection. The electronicallybrakedcycleergometer"Ergometrics800S" (Ergo Line, Medical Measurement Systems; Binz, Germany) was used. The pedal cadence was 70 repetitions per minute. Subjects breathed through low resistance mouthpiece and pulmonary gas exchange parameters $\left(\dot{V}_{2} ; \dot{V}_{\mathrm{CO}_{2}} ; V_{E}\right)$ were measured breath-by-breath using wireless portable spirometry system "Oxycon mobile" (Viasys Healthcare; California, USA). Subjects' $H R$ was recorded simultaneously by $H R$ monitor (S810
Polar, Finland). The seat and handlebar positions on the cycle ergometer were adjusted for each subject prior to initial exercise test and maintained in that position for the subsequent exercise tests.

Incremental cycling exercise. The first and the second ventilation thresholds $\left(\mathrm{VT}_{1}\right.$ and $\mathrm{VT}_{2}$, respectively) and peak oxygen uptake $\left(\dot{V} O_{2 \text { peak }}\right)$ were evaluated using an incremental cycling exercise (ICE) test (two watts (W) every five seconds). The test was started by three min of baseline pedalling at $20 \mathrm{~W}$ and continued until the intensity of cycling could not be maintained at the required level for longer than $10 \mathrm{~s}$. The average value of $\dot{V} \mathrm{O}_{2}$ over the last $30 \mathrm{~s}$ of cycling was referred to as $\dot{V} O_{2 \text { peak }}$ and the $\mathrm{VT}_{1}$ and $\mathrm{VT}_{2}$ were determined from the result of the ICE.

Moderate cycling exercise. The intensity of MC test was $80 \%$ of $\mathrm{VT}_{1}$. The MC was preceded by three min of baseline pedalling at $20 \mathrm{~W}$, then six min $\mathrm{MC}$ and three min baseline $(20 \mathrm{~W})$ were performed.

Cardiorespiratory system parameters kinetics analysis. Cardio respiratory system parameters $\left(\dot{V}_{\mathrm{O}_{2}} ; \dot{V} \mathrm{CO}_{2} ; V_{E} ; \mathrm{HR}\right)$ kinetics during $\mathrm{MC}$ were determined using a mono - exponential model with independent time delays. The following equation was used to model mono - exponential response kinetics:

$$
y(\mathrm{t})=y(\mathrm{~b})+\mathrm{A}\left(1-\mathrm{e}^{-\mathrm{t} / \tau}\right),
$$

where y (t) represents the variable of $\dot{V}_{2} ; \dot{V} \mathrm{CO}_{2} ; V_{E}$ and $H R$ at any time (t); $\mathrm{y}(\mathrm{b})$ is the baseline (average value of last $30 \mathrm{~s}$ during cycling at $20 \mathrm{~W}$ ) of $\dot{V}_{O_{2}} ; \dot{V}_{C O} ; V_{E}$ and $H R$; A is the phase II component amplitude of $y$ response, and $\left(1-\mathrm{e}^{-\mathrm{t} / \tau}\right)$ is the exponential function describing the rate at which $y$ is rising towards the phase II component amplitude. In the exponential function, $\mathrm{t}$ is time; $\tau$ is the phase II component time constant. $\dot{V}_{2} ; \dot{V}_{\mathrm{CO}_{2}}$ and $V_{E}$ data were fit from the phase II response (phase I - "cardiodynamic" increase were removed) to the end of MC, (Rossiter et al., 1999). HR data were modeled mono - exponentially from the onset to the end of MC.

\begin{tabular}{|c|c|c|c|c|c|c|c|}
\hline $\begin{array}{l}\text { Table 1. Subject's descriptive } \\
\text { characteristics. Values are } \\
\text { means (SD) }\end{array}$ & $\begin{array}{l}\text { Subjects } \\
(\mathrm{n}=10)\end{array}$ & $\begin{array}{l}\text { Age, } \\
\text { yrs }\end{array}$ & $\begin{array}{l}\text { Weight, } \\
\text { kg }\end{array}$ & $\begin{array}{l}\text { Height, } \\
\text { m }\end{array}$ & $\begin{array}{l}\text { Free fat } \\
\text { mass, kg }\end{array}$ & $\begin{array}{c}\text { Maximal power, } \\
\text { W }\end{array}$ & $\begin{array}{c}\mathrm{VO}_{2 \text { peak }}, \mathrm{ml} / \\
\mathrm{kg} / \mathrm{min}\end{array}$ \\
\hline $\begin{array}{l}\text { Note. } \mathrm{VO}_{2 \text { peak }}-\text { relative peak } \\
\text { oxygen uptake. }\end{array}$ & $\begin{array}{l}\text { Mean } \\
\text { (SD) }\end{array}$ & $\begin{array}{l}21.7 \\
(1.9)\end{array}$ & $\begin{array}{l}61.1 \\
(4.6)\end{array}$ & $\begin{array}{l}1.71 \\
(0.06)\end{array}$ & $\begin{array}{l}45.1 \\
(2.3)\end{array}$ & $\begin{array}{l}199 \\
(21)\end{array}$ & $\begin{array}{l}35.03 \\
(3.84)\end{array}$ \\
\hline
\end{tabular}


Prior drop jumps. Subjects performed 100 drop jumps from a $0.47 \mathrm{~m}$ stage with $20 \mathrm{~s}$ of recovery between every drop jump. After drop the subject got to amortization phase while the knee joints were flexed at the angle of $90^{\circ}$ when a vertical jump (hands on hips) was performed.

Blood lactate concentration. Blood sample $(25 \mu \mathrm{l})$ for the measurement of blood lactate concentration ([La]) (Accutrend Portable Lactate Analyzer, Roche, Germany) was taken from fingertips.

Muscle soreness and perceived exertion rating. DOMS was reported subjectively performing one squat using a visual scale of $0-10$ points in which 0 represented no pain and 10 represented intolerably intense pain.

The subject was asked to rate their perceived exertion (RPE) using the Borg scale, ranging from 6 to 20 (7 - very, very light; 19 - very, very heavy).

Experimental protocol. Subjects reported to the laboratory on four separated days within a two-three week period. Exercise testing was performed at approximately the same time of day for each subject. The first session was used to familiarize subjects with the testing equipment and procedures. In the same session, each subject performed an ICE test (after five min warm up and five min rest). Subsequently, subjects performed control (CON) $\mathrm{MC}$ in the second session (no sooner than after 48 hours of rest after ICE). On the third occasion subject performed PDJ and after 45 minutes (45'PDJ) they performed the same MC. On the fourth occasion subject performed MC 24 hours after PDJ (24h PDJ). The DOMS was rated $24 \mathrm{~h}$ after PDJ. The [La] was taken and each subject was asked to rate her perceived exertion at the end of MC tests.
Statistical analysis. $\dot{V}_{2}$ and $V_{E}$ were analyzed using two-way repeated measures ANOVA design evaluating time and testing conditions (CON; 45'PDJ; 24h PDJ) as the main effects. $\dot{V}_{2} ; \dot{V}_{C O}$; $V_{E}$ and $H R$ parameters kinetics was analyzed using paired one - way ANOVA (CON; 45'PDJ; 24h PDJ). Significant results were further analyzed using Bonferroni corrections. Statistical significance was accepted when $p<0.05$. All data are reported as the means (SE).

\section{RESEARCH RESULTS}

The power output of MC was 82 (16) W, which corresponds to 40.7 (5.1) percent of maximal power of ICE. There were no significant differences in perceived exertion rating during $\mathrm{MC}$ under $45^{\prime} \mathrm{PDJ}$ (11.7 (1.4) and $24 \mathrm{~h}$ PDJ (11.4 (1.1)) compared with $\mathrm{CON}-(11.7(1.5))$

The absolute $\dot{V}_{2}$ (Figure 1) unaltered during MC under different testing conditions (CON; 45'PDJ; 24h PDJ). The $V_{E}$ (Figure 2) increased during 45'PDJ compared with CON, but the elevation was not statistically significant $(p=0.51)$.

Table 2 shows mean values of base line (b), fast components A and $\tau$ of $\dot{V} O_{2}, \dot{V} \mathrm{CO}_{2}, V_{E}$ and $H R$ respectively, during $\mathrm{MC}$, but there were no significant differences under different testing conditions (CON; 45'PDJ; 24h PDJ). The [La] did not differ 45'PDJ (3.43 (0.98) $\mathrm{mmol} / \mathrm{L})$ and $24 \mathrm{~h}$ PDJ (3.67 (0.98) mmol/L) compared with CON (3.47 $(0.69) \mathrm{mmol} / \mathrm{L})$ at the end of MC. Negative moderate, but not statistically significant $(\mathrm{p}=0.13)$ relationships between $\dot{V} O_{2}$ during $45^{\prime}$ PDJ and DOMS (Figure 3) and $\dot{V O}_{2}$ during 24h PDJ and DOMS (Figure 4) were observed. The mean value of DOMS was 4.8 (2.5) points on a 10 point scale.

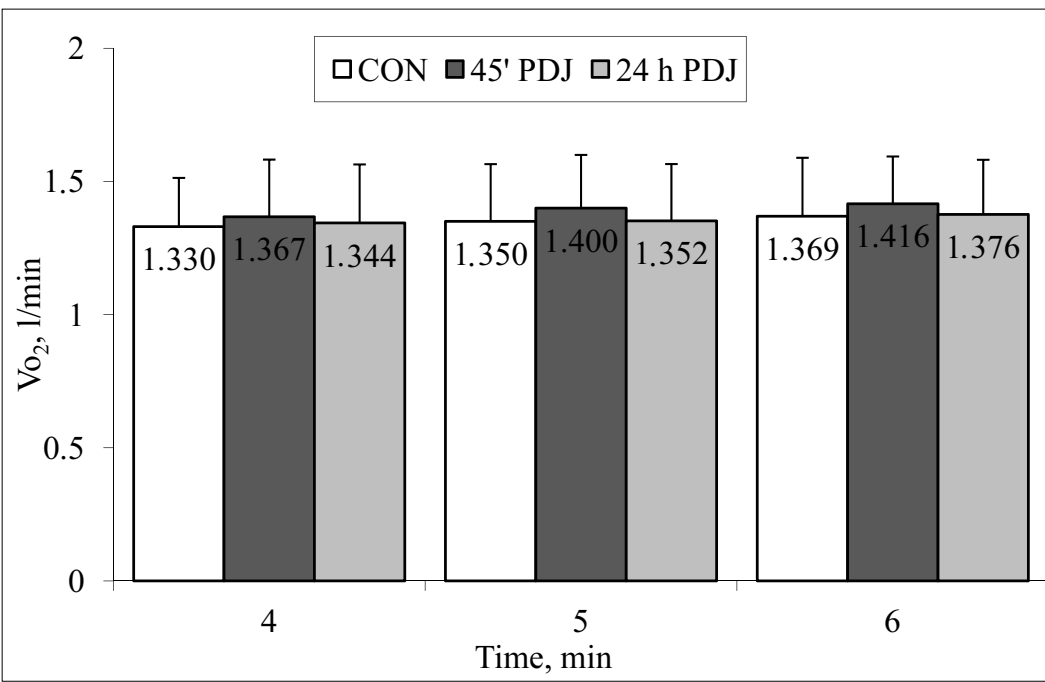

Figure 1. Group mean response of oxygen uptake $\left(\dot{V}_{O_{2}}\right)$ during moderate cycling exercise steady state $(4-6$ minutes) under control condition (CON); 45 minutes (45'PDJ) and 24 hours after prior drop jumps (24h PDJ) 
Table 2. Cardiorespiratory parameter responses to moderate intensity cycling exercise under control 45 min and 24 hours after prior drop jumps

Note. Values are means (SD). $\dot{V}_{\mathrm{O}_{2}}-$ oxygen uptake; $\dot{V}_{\mathrm{CO}_{2}}$ - carbon dioxide output; $V_{E}$ - pulmonary ventilation; $H R$ - heart rate; A - fast component amplitude; $\tau$ - fast component time constant.

\begin{tabular}{|l|c|c|c|}
\hline \multicolumn{1}{|c|}{ Parameters } & $\begin{array}{c}\text { Control } \\
\text { conditions }\end{array}$ & $\begin{array}{c}\text { 45 min after prior } \\
\text { drop jumps }\end{array}$ & $\begin{array}{c}\text { 24 h after prior drop } \\
\text { jumps }\end{array}$ \\
\hline$\dot{V}_{O_{2}}$ baseline, $1 \mathrm{~min}^{-1}$ & $0.700(0.071)$ & $0.692(0.041)$ & $0.714(0.061)$ \\
\hline $\mathrm{A} \dot{V}_{o_{2}}, 1 \mathrm{~min}^{-1}$ & $0.630(0.170)$ & $0.700(0.170)$ & $0.640(0.184)$ \\
\hline$\tau_{1} \dot{V}_{O_{2}}, \mathrm{~s}$ & $32.65(8.33)$ & $32.85(9.73)$ & $29.22(8.75)$ \\
\hline$\dot{V}_{C O_{2}}$ baseline, $1 \mathrm{~min}^{-1}$ & $0.550(0.064)$ & $0.554(0.056)$ & $0.563(0.069)$ \\
\hline $\mathrm{A} \dot{V}_{c o}, 1 \mathrm{~min}{ }^{-1}$ & $0.74(0.17)$ & $0.80(0.18)$ & $0.76(0.19)$ \\
\hline$\tau \dot{V}_{c O_{2}}, \mathrm{~s}$ & $58.25(10.41)$ & $53.8(23.00)$ & $56.9(21.18)$ \\
\hline$V_{E}$ baseline, $1 \mathrm{~min}^{-1}$ & $18.82(2.64)$ & $19.03(2.77)$ & $19.01(2.73)$ \\
\hline $\mathrm{A} V_{E}, 1 \mathrm{~min}^{-1}$ & $19.74(4.68)$ & $21.96(4.46)$ & $19.82(5.38)$ \\
\hline$\tau V_{E}, \mathrm{~s}$ & $77.34(18.18)$ & $68.62(19.45)$ & $76.04(34.59)$ \\
\hline$H R$ baseline, $1 \mathrm{~min}^{-1}$ & $103.4(13.0)$ & $104.0(10.1)$ & $98.7(8.3)$ \\
\hline $\mathrm{A} H R 1 \mathrm{~min}^{-1}$ & $40.4(4.7)$ & $43.7(5.0)$ & $39.7(5.3)$ \\
\hline$\tau H R, \mathrm{~s}$ & $61.52(12.12)$ & $57.59(15.11)$ & $55.65(12.51)$ \\
\hline
\end{tabular}

Figure 2. Group mean response of pulmonary ventilation $\left(V_{E}\right)$ during moderate cycling exercise steady state (4-6 minutes) under control condition (CON); 45 minutes (45'PDJ) and 24 hours after prior drop jumps (24h PDJ)

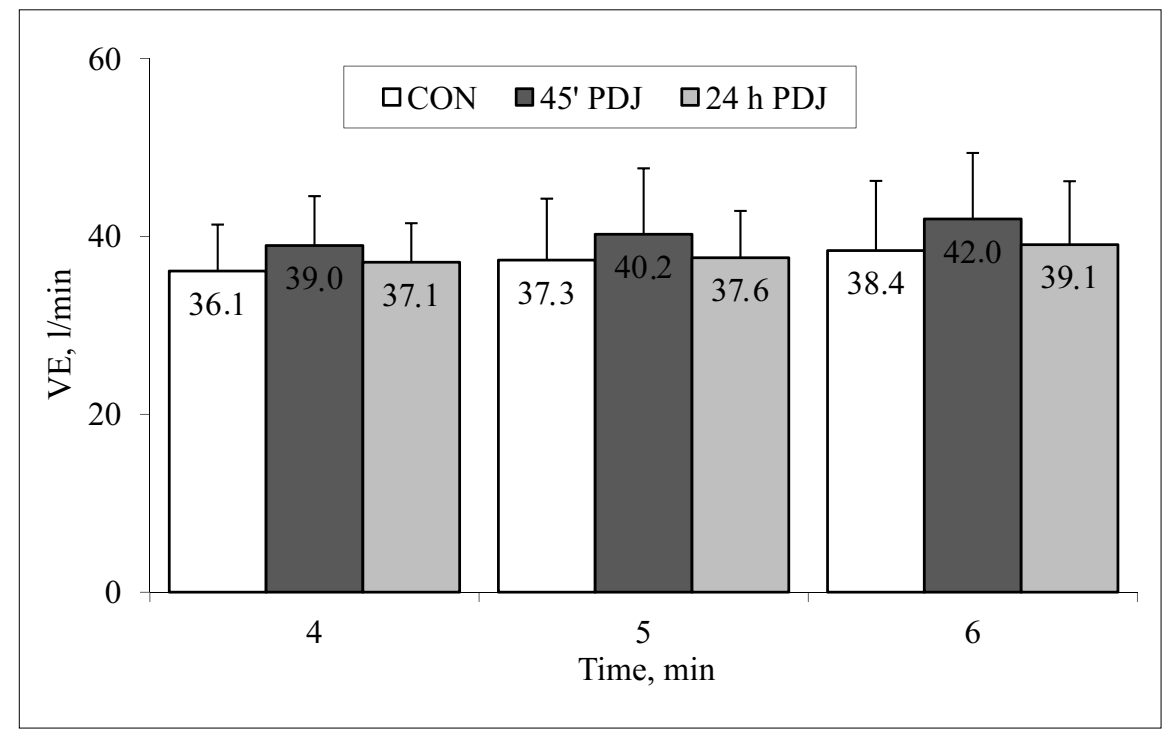

Figure 3. The correlation between changes (from control moderate cycling conditions (CON)) on oxygen uptake $\left(\Delta \mathrm{VO}_{2}\right)$ during moderate cycling 45 minutes after prior drop jumps and delayed onset muscle soreness (DOMS) 24 hours after prior drop jumps

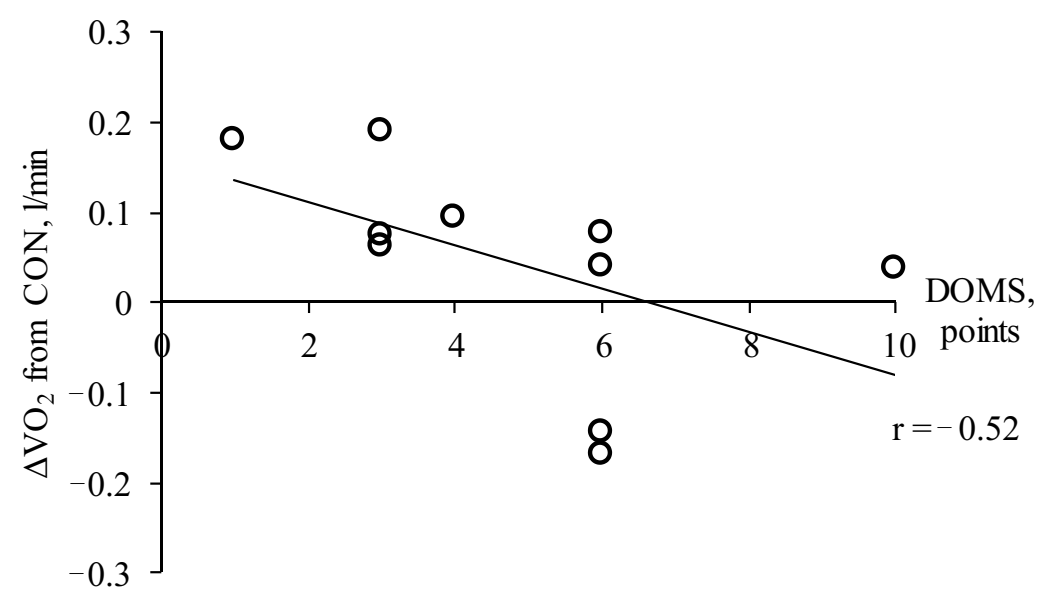




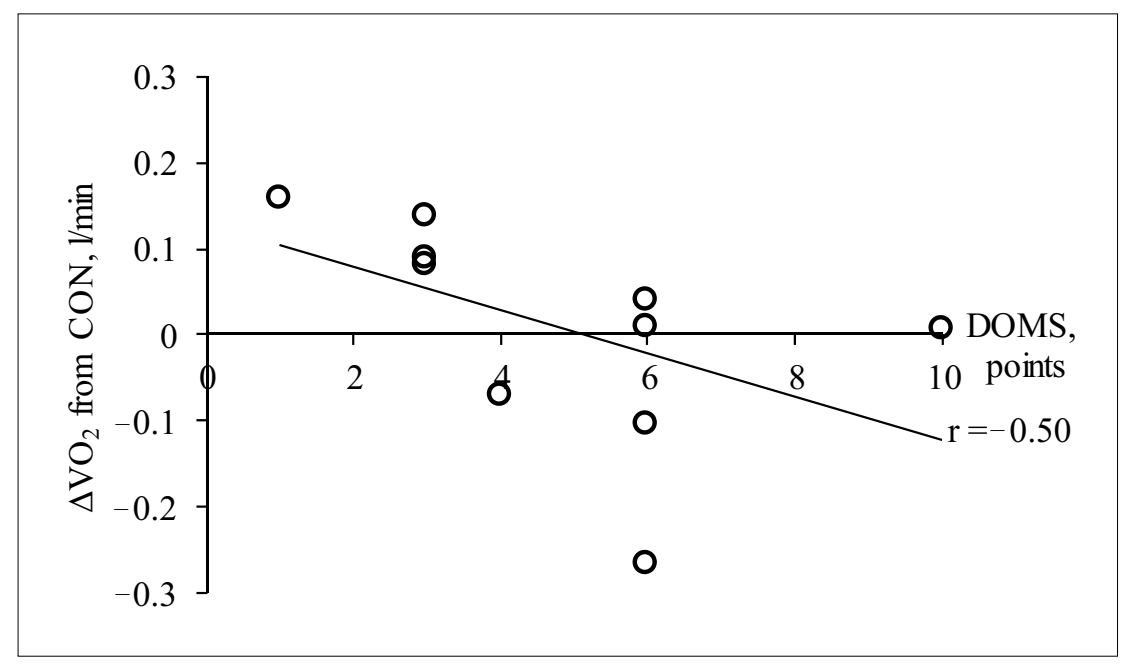

Figure 4. The correlation between changes (from control moderate cycling conditions (CON)) on oxygen uptake $\left(\Delta \mathrm{VO}_{2}\right)$ during moderate cycling 24 hours after prior drop jumps and delayed onset muscle soreness (DOMS) 24 hours after prior drop jumps

\section{DISCUSSION}

This is the first study examining cardiorespiratory parameters response to PDJ 45 minutes and 24 hours after PDJ during MC in young women. The main finding of this study is that PDJ does not change the steady state of $\dot{V}_{2}$ and cardiorespiratory parameters phase II kinetics, but has a tendency to elevate $V_{E}$ during moderate cycling 45 minutes after PDJ.

As expected, moderate DOMS was induced in thighs muscles after 24 hours in the present study. Drop jumps from a $0.4-0.5 \mathrm{~m}$ high platform (Nielsen et al., 2005; Ratkevičius et al., 2006; Skurvydas et al., 2007; Gorianovas et al., 2010) either bench stepping exercise (Gleeson et al., 1995; Schneider et al., 2007) or squats with a load corresponding 70-150 percents of body mass (Moysi et al., 2005; Davies et al., 2009) are commonly used to induce DOMS, which is first felt $6-10$ hours post exercise and peaks between 24 and 78 hours post exercise. Unfortunately, changes in force generating capacity of thigh muscles and CK activity in blood were not measured in our study, but our experiment was performed like in the previous study and represented maximal voluntary contraction (MVC) decrease by $\sim 20 \%$ as measured one hour post-exercise (Skurvydas et al., 2000) and still shows deficit within 72 hours and CK activity increase within 24-48 hours of recovery (Nielen et al., 2005; Skurvydas et al., 2007; Gorianovas et al., 2010). Thus, it is reasonable to assume that muscle damage was induced in the present study.

Previously study results showed no residual effect of on $\dot{V} \mathrm{O}_{2}$ during heavy (Gleeson et al., 1995; Moysi et al., 2005; Schneider et al., 2007) and moderate (Davies et al., 2009) cycling performed 24-72 hours after eccentric exercise in men or women. However, in contrast, increased $\dot{V} \mathrm{O}_{2}$ has been reported during steady state phase at three different cycling intensities $(\sim 40 ; 50$ and $65 \%$ of $\dot{V} O_{2 \text { peak }}$ ) in men (Ratkevičius et al., 2006) and during moderate running in women one hour after eccentric exercise (Zaičenkovienè, Stasiulis, 2010). Sustaining these findings, it is possible to suppose that prior eccentric exercises elevate $\dot{V} O_{2}$ of steady state phase during constant cycling and running one hour after DOMS inducing exercise, but in the present study unaltered absolute $\dot{V} \mathrm{O}_{2}$ of steady state phase during $\mathrm{MC}$ performed 45 minutes after PDJ is in contrast with this assumption. However, unaltered $\dot{V} \mathrm{O}_{2}$ during $\mathrm{MC}$ performed $24 \mathrm{~h}$ after PDJ concurs with previous studies, demonstrating no residual effect on $\dot{V} O_{2}$ during constant cycling within 24-72 hours post eccentric exercises (Gleeson et al., 1995; Moysi et al., 2005; Schneider et al., 2007; Davies et al., 2009). Moreover, in the present study, negative insignificant correlation which has been observed between DOMS and $\dot{V}_{O_{2}}$ (see Figures 3 and 4) did not confirm DOMS negative impact on $\dot{V}_{O_{2}}$. Hence we may infer that eccentric exercise has slight residual effect within the first hour of recovery, with no alteration on $\dot{V} \mathrm{O}_{2}$ 24-72 during constant cycling. However, elevated $V_{E}$ and [La] and HR have been previously observed (Gleeson et al., 1995; Schneider et al., 2007; Davies et al., 2009) with increases in ratings of perceived exertion during constant exercise (Gleeson et al., 1995; Zaičenkovienè, Stasiulis, 2010) 1-48 hours after eccentric exercise. In the present study, $V_{E}$ tended to increase after 45 minutes, but [La] and RPE were unaltered after PDJ 45 minutes and 24 
hours of recovery. Increases in $V_{E}$ observed whilst exercising with DOMS have been associated with the additional recruitment of type II fibers and a concomitant rise in the rate of glycogenolysis (Chein et al., 2007) and in turn increased RPE (Davies et al., 2009). Contrary, increases in RPE with no alteration in $V_{E}$ have been found (Zaičenkovienè, Stasiulis, 2010) during moderate running, conversely, elevated $V_{E}$ with no changes in a sense of effort have been observed during moderate exercise one hour after PDJ in the present study. The concert between $V_{E}$, [La] and RPE are still contradictory. Despite the unclear reason of elevation in $V_{E}$, it is one of the most sensitive cardiorespirarory parameters which could be altered by eccentric exercise.

\section{CONCLUSIONS AND PERSPECTIVES}

In conclusion, prior drop jumps have induced delayed onset muscle soreness after 24 hours of recovery. The delayed onset muscle soreness does not change during the steady state of oxygen uptake, carbon dioxide output and heart rate phase II kinetics both after 45 minutes and 24 hours after prior drop jumps, but it tends to elevate ventilation 45 minutes after prior drop jumps during moderate cycling exercise. The delayed onset muscle soreness does not alter blood lactate concentration and perceived exertion ratings during moderate cycling exercise in young women.

\section{REFERENCES}

Chen, T. C., Lin, K. Y., Chen, H. L., Lin, M. J., Nosaka, K. (2011). Comparison in eccentric exerciseinduced muscle damage among four limb muscles. European Journal of Applied Physiology, 111, 211-223. Chen, T. C., Nosak, K., Tu, J. H. (2007). Changes in running economy following downhill running. Journal of Sport Science, 25, 55-63.

Davies, C. R., Rowlands, A.,V., Eston, R. G. (2009). Effect of exercise-induced muscle damage on ventilatory and perceived exertion responses to moderate and severe intensity cycle exercise. European Journal of Applied Physiology, 107, 11-19.

Gleeson, M., Blannin, A. K., Zhu, B., Brooks, S., Cave, R. (1995). Cardiorespiratory, hormonal and haematological responses to submaximal cycling performed 2 days after eccentric or concentric exercise bouts. Journal of Sport and Exercise, 6, 471-479.

Gorianovas. G., Streckis, V., Skurvydas, A. et al. (2010). Does the repeated bout effect of exercise evoke similar changes in the motor system of men and women? Ugdymas. Kūno kultūra. Sportas, 1 (76), 32-38.

Hortobagyi, T., Hill, J. P., Houmard, J. A. et al. (1998). Adaptive responses to muscle lengthening and shortening in humans. Journal of Applied Physiology, 80, 765-772.

Laaksonen, M. S., Kivelä, R., Kyröläinen, H. et al. (2006). Effects of exhaustive stretch-shortening cycle exercise on muscle blood flow during exercise. Acta Physiologica (Oxfors), 186 (4), 261-270.

Malm, C., Yu, J. G. (2012). Exercise-induced muscle damage and inflammation: Re-evaluation by proteomics. Histochemestry and Cell Biology, Apr 10 [Epub.].

Moysi, J. S., Garcia-Romero, J. C., Alvero-Cruz, J. R. et al. (2005). Effects of eccentric exercise on cycling efficiency. Canadian Journal of Applied Physiology, 30, 259-275.
Nielsen, J. S., Madsen, K., Jørgensen, L. V., Sahlin, K. (2005). Effects of lengthening contraction on calcium kinetics and skeletal muscle contractility in humans. Acta Physiologica Scandinavica, 184, 203-214.

Ratkevičius, A., Stasiulis, A., Dubininkaitè, L., Skurvydas, A. (2006). Muscle fatigue increases metabolic costs of ergometer cycling without changing $\mathrm{VO}_{2}$ slow component. Journal of Sports Science and Medicine, 5, 440-448.

Rossiter, H. B., Ward, S. A., Doyle, V. L. et al. (1999). Inferences from pulmonary $\mathrm{O}_{2}$ uptake with respect to intramuscular [phosphocreatine] kinetics during moderate exercise in humans. Journal of Physiology, 518 (3), 921-932.

Schneider, D. A., Berwick, J. P., Sabapathy, S. Minahan, C. (2007). $\mathrm{VO}_{2}$ uptake kinetics during exercise with DOMS. International Journal of Sports Medicine, 28, 1-7.

Semmler, J. G., Tucker, K. J., Allen, T. J. (2007). Eccentric exercise increases EMG amplitude and force fluctuations during submaximal contractions of elbow flexor muscles. Journal of Applied Physiology, 103, 979-989.

Skurvydas, A., Brazaitis, M., Kamandulis, S. (2010). Prolonged muscle damage depends on force variability. International Journal of Sport and Medicine, 31, 77-81.

Skurvydas, A., Jascaninas, J., Zachovajevas, P. (2000). Changes in height of jump, maximal voluntary contraction force and low-frequency fatigue after 100 intermittent or continuous with maximal intensity. Acta Physiologica Scandinavica, 169, 55-62.

Skurvydas, A., Mamkus, G., Dudoniene, V. et al. (2007). The time-course of voluntary and electrically evoked muscle performance during and after stretch-shortening exercise is different. Journal of Sports Science and Medicine, 6, 408-416.

Stupka, N., Lowther, S., Chorneyko, K. et al. (2000). 
Gender differences in muscle inflammation after eccentric exercise. Journal of Applied Physiology, 89, 2325-2332.

Twist. C., Eston, R. G. (2009). The effect of exerciseinduced muscle damage on perceived exertion and cycling endurance performance. European Journal of
Applied Physiology 105, 559-567.

Zaičenkoviene, K., Stasiulis, A. (2010). The effect of preceding drop jumps on $\mathrm{VO}_{2}$ kinetics during moderate and heavy intensity running in young women. Ugdymas. Kūno kultūra. Sportas, 3 (78), 105-112.

\title{
ŠUOLIŲ PRIEŠKRŪVIO POVEIKIS MERGINŲ KVĖPAVIMO BEI ŠIRDIES IR KRAUJAGYSLIŲ SISTEMU巳 RODIKLIŲ KAITAI ATLIEKANT VIDUTINIO INTENSYVUMO KRŪVI VELOERGOMETRU
}

\author{
Neringa Baranauskienė, Arvydas Stasiulis \\ Lietuvos kūno kultūros akademija, Kaunas, Lietuva
}

\section{SANTRAUKA}

Tyrimo pagrindimas ir hipotezė. Neịprasti nušokimai vertikaliu šuoliu (NVŠ) sukelia raumenų pažaidą, lydimą vèluojančio raumenų skausmo ir sumažejusio koncentrinių susitraukimų atlikimo veiksmingumu, tačiau nėra aišku, koks NVŠ liekamasis poveikis širdies ir kraujagyslių bei kvėpavimo sistemų rodikliams, jų kaitai atliekant vidutini krūvį veloergometru (VK). Manoma, kad atliekant VK po ekscentrinių pratimų pakis širdies ir kraujagyslių bei kvėpavimo sistemų funkcijų rodikliai.

Tikslas - nustatyti 100 NVŠ poveiki širdies ir kraujagyslių bei kvėpavimo sistemų funkcjų rodiklių kaitai atliekant VK.

Metodai. Skirtingų testavimų metu 10 merginų atliko vieną nuosekliai didinamą krūvi, per kitus tris kartus (kontrolini, praejus 45 minutėms ir 24 valandoms po NVŠ) - VK veloergometru („Ergotine-800“, Vokietija). Mynimo dažnumas $-70 \mathrm{k}$./min. VK metu buvo registruojamas deguonies suvartojimas $\left(\dot{V}_{O_{2}}\right)$, anglies dioksido išskyrimas ( $\left.\dot{V} \mathrm{CO}_{2}\right)$, minutiné plaučiu ventiliacija $\left(V_{E}\right)$ ir širdies susitraukimų dažnis $(\breve{S} S ̌ D)$. VK pabaigoje buvo vertinamos subjektyviai suvokiamos pastangos. Praėjus 24 valandoms po NVŠ, tiriamosios vertino skausmą.

Rezultatai. Tiriamosios jautė vidutini šlaunies raumenų skausmą praejus 24 valandoms po NVŠ $(5,0)(2,79)$ balų). Praejjus 45 minutėms ir 24 valandoms po VK, $\dot{V}_{2}, \dot{V} c O_{2}$ ir ŠSD nepakito, tačiau $V_{E}$ po 45 minučių didejjo, bet nereikšmingai. Buvo nustatytas neigiamas koreliacinis ryšys tarp VRS ir $\dot{V O}_{2}(\mathrm{r}=-0.52)$.

Aptarimas ir išvados. Apibendrinant galima teigti, kad 100 nušokimų vertikaliu šuoliu, praejjus 45 minutėms 24 valandoms po jų, neturi reikšmingo poveikio moterų kvėpavimo ir širdies bei kraujagyslių sistemų rodiklių kaitai, tačiau turi tendenciją padidinti $V_{E}$ praejjus 45 minutèms po NŠV, kai atliekamas vidutinio intensyvumo krūvis veloergometru.

Raktažodžiai: vėluojantis raumenų skausmas, deguonies suvartojimas, pastovus krūvis.

Gauta 2012 m. birželio $27 \mathrm{~d}$.

Received on June 27, 2012 